IRA-International Journal of Management \& Social Sciences

ISSN 2455-2267; Vol.06, Issue 02 (2017)

Pg. no. 298-305

Institute of Research Advances

https://research-advances.org/index.php/RAJMSS

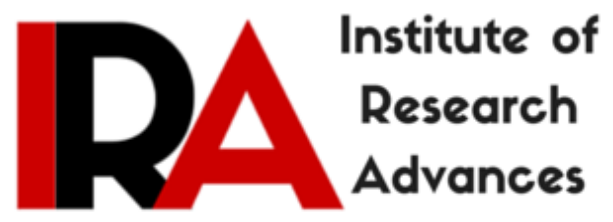

\title{
Sociology and the Crisis of Social Transformation in India in the Aspect of Information Technology
}

\section{Dr. Preeti Srivastava}

Assistant Professor, Department of Sociology, P.B.P.G. College, Pratapgarh City, India.

Type of Review: Peer Reviewed.

DOI: http://dx.doi.org/10.21013/jmss.v6.n2.p14

\section{How to cite this paper:}

Srivastava, P. (2017). Sociology and the Crisis of Social Transformation in India in the Aspect of Information Technology. IRA-International Journal of Management \& Social Sciences (ISSN 2455-2267), 6(2), 298-305. doi:http://dx.doi.org/10.21013/jmss.v6.n2.p14

(C) Institute of Research Advances

\section{(cc) EY-NC}

This work is licensed under a Creative Commons Attribution-Non Commercial 4.0 International License subject to proper citation to the publication source of the work.

Disclaimer: The scholarly papers as reviewed and published by the Institute of Research Advances (IRA) are the views and opinions of their respective authors and are not the views or opinions of the IRA. The IRA disclaims of any harm or loss caused due to the published content to any party. 


\begin{abstract}
Sociology is a social science that studies society and the individual in perspective of society. Sociology emerged as a separate discipline in the mid-1800s in Western Europe during the onset of the Industrial Revolution. Industrialization brought Social Changes so sweeping they affected all aspects of human existence-where people lived, the nature of their work and interpersonal relationships. Social change, a shift in the characteristics of culture and society is such a vital part of Social life. Social Transformation is the process by which an individual alters the socially ascribed social status of their parents into a socially achieved status for themselves. However another definition refers to large scale Social Change as in Cultural Reforms or Transformation.

The main objectives of this research paper are-1) To assess that Technology especially information technology plays a vital role in social transformation. 2) To identify that they are positively related to each other. 3) to evaluate the seriousness of cyber threats.

Indian country is proposed as an area of survey for conducting the study of above-mentioned objectives. Percentile, growth rate and charge are used to justify it.

Most popular information technology skills at the moment are internet (Computer networking). According to a release dated September 19, 2006, the Internet and Mobile Association of India (IAMAI) and IMRB International, Internet users in India have reached 37 million in the month of September 2006, up from 33 million in March 2006. During the same period the number of "Active Users" has risen from 21.1 Million in March 2006 to 25 Million in September 2006. "Active User' is an internationally accepted and widely used category to define users who have used the internet at least one in the last 30 days.

India has been facing serious cyber threats these days. These include threats from cyber espionage, cyber terrorism, cyber warfare, etc. Governments can facilitate these processes by taking legislative measures that ensure human rights are protected online just as they are physical spaces.
\end{abstract}

\title{
$\underline{\text { Part-1 }}$
}

Sociology is a social science that studies society and the individual in perspective of society. The origins of Sociology lie in the $19^{\text {th }}$ century but during 1960-70 it became a major Social Science subject taught in Universities/Colleges and Schools, It is the study of the Social lives of humans groups and societies. It concerns itself with the Social rules and processes that bind and separate people not only as individual but as members of associations, groups and institutions. It is interested in our behavior as social beings. Thus the Sociological field of interest ranges from the analysis of short contacts between anonymous individuals on the street to the study of global social processes. As Morris Ginsberg has said, "Sociology is the study of human interactions and interrelations their conditions and consequences." (Gupta and Sharma, 2000)

Sociology emerged as a separate discipline in the mid-1800s in Western Europe during the onset of the Industrial Revolution. Industrialization brought Social Changes so sweeping they affected all aspects of human existence-where people lived, the nature of their work and interpersonal relationships. Early Sociologists who focused on these social changes include Auguste Comte, Herbert Spencer, Karl Marx, Harriet Martineau, Emile Durkheim and Max Webber. Social change, a shift in the characteristics of culture and society is such a vital part of Social life. According to Jones, "Social change is a word used to describe variations in or modification of any aspect of Social Process, Social Patterns, Social Interactions or Social Organization." (Gupta and Sharma, 2000) 


\section{SOCIAL TRANSFORMATION}

Social Transformation is the process by which an individual alters the socially ascribed social status of their parents into a socially achieved status for themselves. However another definition refers to large scale Social Change as in Cultural Reforms or Transformation. Therefore it can be said that Social Transformation is considered an interpersonal negotiation because it requires that the individual have their social position be validated by others for transformation. It is a reciprocal relationship in which people have to be embraced and correctly identified with the cultural expectations of their particulars class membership. This is the only way that persons can advance from their own ascribed status to a new achieved status.

According to K. Davis, "By Social Transformation is meant only such alterations as occur in social organization that is the structure and functions of society." Social Transformation in this context requires a shift in collective consciousness of society local, state, national or global so that reality is refined by consensus. This often happens by external stimulus and sometimes internally. Chart-1 throws the light on ongoing social transformation and advent of new social value (rajee.sulekha.com). In mathematically, it can be written as-

$$
\text { S.T. }=\mathbf{f}(\mathrm{M}, \mathrm{C}, \mathrm{COM}, \mathrm{T}, \mathrm{E})
$$

where, S.T., M. C. COM, T and E stand for social transformation, materialism, consumerism, communication, technology and environment respectively. At ceteris paribus, Technology plays a vital role in social transformation. They are positively related to each other. A simple and useful definition of technology is tools, items used to accomplish tasks.

\section{CHART-1}

EMERGING SOCIAL STRATAGEM IN INDIA-ONGOING SOCIAL TRANSFORMATION AND ADVENT OF NEW SOCIAL VALUES: SOCIAL TRANSFORMATION

\begin{tabular}{|c|c|c|c|c|c|c|}
\hline \multicolumn{4}{|c|}{ CAUSES } & \multicolumn{3}{|c|}{ EFFECTS } \\
\hline \multicolumn{3}{|c|}{ MATERIALISM } & & \multicolumn{3}{|c|}{ AWARENESS } \\
\hline \multicolumn{3}{|c|}{ CONSUMERISM } & & \multicolumn{3}{|c|}{ SELF AWAKENING } \\
\hline \multicolumn{3}{|c|}{ COMMUNICATION } & & \multicolumn{3}{|c|}{ RISING ASPIRATIONS } \\
\hline \multicolumn{3}{|c|}{ TECHNOLOGY } & & \multicolumn{3}{|c|}{ DEMASSIFICATION } \\
\hline \multicolumn{4}{|c|}{ ENVIRONMENTS } & \multicolumn{3}{|c|}{ NUCLEAR FAMILY } \\
\hline \multicolumn{4}{|c|}{ UNIFORMITY IS THE KEY TRAIT } & \multicolumn{3}{|c|}{ DIVERSITY IS THE KEY TRAIT } \\
\hline \multicolumn{3}{|c|}{$\frac{\text { OLD SOCIAL }}{\underline{\text { ORDER }}}$} & & \multicolumn{3}{|c|}{$\frac{\text { NEW SOCIAL }}{\underline{\text { ORDER }}}$} \\
\hline THEME & TREND & EFFECT & $\mathbf{T}$ & THEME & TREND & EFFECT \\
\hline $\begin{array}{l}\text { FAMILY } \\
\text { MAN }\end{array}$ & $\begin{array}{l}\text { NO SELF } \\
\text { IDENTITY }\end{array}$ & $\begin{array}{c}\text { FAMILY } \\
\text { INTEREST } \\
\text { SUPREME }\end{array}$ & $\begin{array}{l}\mathbf{R} \\
\mathbf{A} \\
\mathbf{N} \\
\mathbf{S}\end{array}$ & INDIVIDUALISTIC & $\begin{array}{c}\text { SELF- } \\
\text { IDENTITY }\end{array}$ & $\begin{array}{c}\text { SELF } \\
\text { INTERESTS } \\
\text { SUPREME }\end{array}$ \\
\hline $\begin{array}{l}\text { FAMILY } \\
\text { HEAD IS } \\
\text { MESSIAH }\end{array}$ & $\begin{array}{l}\text { RESPECT } \\
\text { FAMILY } \\
\text { ELDERS }\end{array}$ & $\begin{array}{c}\text { AMENABLE } \\
\text { TO } \\
\text { AUTHORITY }\end{array}$ & $\begin{array}{l}\mathbf{I} \\
\mathbf{T} \\
\mathbf{O} \\
\mathbf{N}\end{array}$ & $\begin{array}{c}\text { SELF IS } \\
\text { SUPREME }\end{array}$ & $\begin{array}{l}\text { INSENSITIVE } \\
\text { TO OTHERS }\end{array}$ & $\begin{array}{c}\text { NOT } \\
\text { AMENABLE } \\
\text { TO } \\
\text { AUTHORITY }\end{array}$ \\
\hline $\begin{array}{c}\text { FAMILY } \\
\text { GOALS } \\
\text { SUPREME }\end{array}$ & $\begin{array}{c}\text { MEANS } \\
\text { IMPORTANT } \\
\text { NOT END }\end{array}$ & $\begin{array}{c}\text { UPHOLD } \\
\text { FAMILY } \\
\text { ETHOS }\end{array}$ & $\begin{array}{l}\mathbf{A} \\
\mathbf{L} \\
\mathbf{S}\end{array}$ & $\begin{array}{c}\text { SELF GOALS } \\
\text { THRU ANY MEANS }\end{array}$ & $\begin{array}{c}\text { END } \\
\text { JUSTIFY } \\
\text { MEANS }\end{array}$ & $\begin{array}{c}\text { SELF } \\
\text { ORIENTED }\end{array}$ \\
\hline $\begin{array}{c}\text { SELF- } \\
\text { CONTENT- } \\
\text { MENT }\end{array}$ & $\begin{array}{c}\text { CURB } \\
\text { PERSONAL } \\
\text { DESIRES }\end{array}$ & $\begin{array}{c}\text { PEACE } \\
\text { AND } \\
\text { HARMONY }\end{array}$ & $\begin{array}{l}\text { O } \\
\text { C } \\
\text { I }\end{array}$ & $\begin{array}{c}\text { ASPIRING } \\
\text { AND } \\
\text { AMBITIOUS }\end{array}$ & $\begin{array}{c}\text { RISING } \\
\text { EXPECTATION }\end{array}$ & $\begin{array}{c}\text { CONFLICT } \\
\text { AND } \\
\text { QUESTION }\end{array}$ \\
\hline
\end{tabular}




\begin{tabular}{|c|c|c|c|}
\hline & $\mathbf{E}$ & & \\
MASSIFIED AND A & $\mathbf{T}$ & DEMASSIFIED AND A \\
NON INFORMED SOCIETY & $\mathbf{Y}$ & KNOWLEDGEABLE SOCIETY \\
\cline { 4 - 4 } LARGE IS STRENGTH & & SMALL IS BEAUTIFUL \\
\hline TREASURE YOUR OLD & & DISPOSABLE CULTURE \\
\hline
\end{tabular}

Modern Technology is so advanced that experts are able to build space platforms and send people to the moon. Therefore, Technology changes society without automobiles, telephones, televisions, and computers and so on our entire way of life would be strikingly different. It affects the way people live and finally at its impact on the natural environment. There are four types of technology-

1. Primitive Technology-the adaptation of natural items for human use.

2. Industrial Technology-technology centered on machines powered by fuels instead of natural forces such as wild and rivers.

3. Postindustrial Technology-technology centering on information, transportation, and communication.

4. New Technology-technology, if it is ever developed, that will be such a leap forward that it cannot be classified as simply an extension of current technology.

When a technology is introduced into a society, it forces other parts of society to give way. In fact, a new technology can reshape an entire society in many forms such as- Transformation of Existing Technologies, Changes in Social Organization, Changes in Ideology, Transformation of Values and Transformation of Social Relationship.

\section{Part-II}

\section{INFORMATION TECHNOLOGY}

The term information technology or IT refers to an entire industry. In actuality, information technology is the use of computers and software to manage information. In some companies, this is referred to as Management information Services (or MIS) or simply as Information Services (or IS). According to the definition adopted by UNESCO, the Information Technology (IT)- a set of interrelated scientific, technological and engineering disciplines are studying methods of effective labor organization of people employed information processing and storage, computing, and methods of organization and interaction with people and manufacturing facilities, their practical applications, as well as associated with all their social, economic and cultural issues. Information Technology has already been blamed, among other things for:

- creating unemployment

- deskilling jobs

- reducing the ability of governments to control their economies

- invading privacy

- increasing delinquency in children

- manipulation of the 'truth'

- pornography

It is about to be blamed for, if it has not already:

- destroying cities

- threatening the countryside

- terrorism

- anarchy

- destroying culture 
- destabilizing the state and more....

\section{OBJECTIVES OF THIS RESEARCH PAPER}

The main objectives of this research paper are- 1) To assess that Technology especially information technology plays a vital role in social transformation. 2) To identify that they are positively related to each other. 3) To evaluate the seriousness of cyber threats.

\section{METHODOLOGY OF THIS RESEARCH PAPER}

Indian country is proposed as an area of survey for conducting the study of abovementioned objectives. Percentile, growth rate and chart are used to justify it.

\section{STATISTICS OF THIS RESEARCH PAPER}

Most popular information technology skills at the moment are internet (Computer networking). According to a release dated September 19, 2006, the Internet and Mobile Association of India (IAMAI) and IMRB International, Internet users in India have reached 37 million in the month of September 2006, up from 33 million in March 2006. During the same period the number of "active users" has risen from 21.1 Million in March 2006 to 25 Million in September 2006. "Active User" in an internationally accepted and widely used category to define users who have used the internet at least once in the last 30 days.

The numbers are a result of the largest "offline" survey so far carried out in India to estimate the "ever user" and "active user" categories. The primary survey for the study was conducted in early 2006 amongst 16,500 households covering 65,000 individuals across 26 major metros and small towns in India, with additional coverage of 10,000 business and 250 cyber café owners. The survey did not include rural areas. First there was the IAMAI report, which pegged the number of active Internet users in India at 25 million. As per Juxt Consult's 'India Online 2007', there are 25 million active Internet users in India. TRAI figures put the Indian Internet subscriber base at 8.582 million. Following are some of the highlights of the report:

- Indian Internet population stands at 22 million in April 2007, a 10 percent jump from 20 million in November 2006.

- Yahoo was the most visited website network with 14 million unique visitors (growth of 9\% between November 2006 to April 2007).

- Google came in second with 13.9 million unique visitors with a 16\% growth between Nov 06 to April 07.

- Microsoft came in at number 3 with 10.3 million visitors.

- Time Warner Network had 4 million unique visitors and also grew the fastest (74\%) over the six months.

- Average time spent by a user on Google was 4.5 hours as compared to Yahoo's 4.2 hours and Microsoft's 1.6 hours.

- Corporate websites are the most visited category of websites in India (73\%). Services (message boards, chat, forums, email) came in second with $72 \%$ and portals came in at $70 \%$. $52 \%$ of online Indian audiences visit entertainment websites and the same number also visit social networking websites.

- Yahoo, Google, Microsoft, Rediff and India Times as the top five visited websites by Indians.

Internet Usage and Population Statistics:

\begin{tabular}{|c|l|l|l|l|}
\hline YEAR & \multicolumn{1}{|c|}{ Users } & \multicolumn{1}{|c|}{ Population } & \% Per. & Usage Source \\
\hline $\mathbf{1 9 9 8}$ & $1,400,000$ & $1,094,870,677$ & $0.1 \%$ & ITU \\
\hline $\mathbf{1 9 9 9}$ & $2,800,000$ & $1,094,870,677$ & $0.3 \%$ & ITU \\
\hline $\mathbf{2 0 0 0}$ & $5,500,000$ & $1,094,870,677$ & $0.5 \%$ & ITU \\
\hline
\end{tabular}




\begin{tabular}{|l|l|l|l|l|}
\hline $\mathbf{2 0 0 1}$ & $7,000,000$ & $1,094,870,677$ & $0.7 \%$ & ITU \\
\hline $\mathbf{2 0 0 2}$ & $16,500,000$ & $1,094,870,677$ & $1.6 \%$ & ITU \\
\hline $\mathbf{2 0 0 3}$ & $22,500,000$ & $1,094,870,677$ & $2.1 \%$ & ITU \\
\hline $\mathbf{2 0 0 4}$ & $39,200,000$ & $1,094,870,677$ & $3.6 \%$ & C.I. Almanac \\
\hline $\mathbf{2 0 0 5}$ & $50,600,000$ & $1,112,225,812$ & $4.5 \%$ & C.I. Almanac \\
\hline $\mathbf{2 0 0 6}$ & $40,000,000$ & $1,112,225,812$ & $3.6 \%$ & IAMAI \\
\hline $\mathbf{2 0 0 7}$ & $42,000,000$ & $1,129,667,528$ & $3.7 \%$ & IWS \\
\hline $\mathbf{2 0 0 9}$ & $81,000,000$ & $1,156,897,766$ & $7.0 \%$ & ITU \\
\hline $\mathbf{2 0 1 0}$ & $100.000,000$ & $1,173,108,018$ & $8.5 \%$ & IWS \\
\hline
\end{tabular}

Sources: http://www.defence.pk/forums/india-defence/100765-india-facing-serious-cyberthreats.html

In India Context, the internet has opened up a world of new opportunity for gender activists and development actors working in the arena of information and communications technologies (ICTs). The need for access, connectivity and relevant content has been well argued by researchers and advocates alike, but as the reach of the internet expands, new issues arise in bridging the 'digital divide'. Invasions of privacy, objectionable and malicious content, cyber harassment and other forms of 'cybercrimes' undermine the internet's potential as a great equalizer and threaten autonomy and security of individuals, organizations and communities and nations.

On the one hand, ICTs have created opportunities to combat inequality through movements and communities against issues that were once deemed 'private', such as domestic violence and sex trafficking. On the other hand, ICTs exacerbate existing structures of inequality by enabling cybercriminals to access and misuse private information to target vulnerable groups.

\section{$\underline{\text { Part-III }}$}

\section{INDIA IS FACING SERIOUS CYBER THREATS}

India has been facing serious cyber threats these days. These include threats from cyber espionage, cyber terrorism. cyber warfare, etc. Even social networking sites and cloud computing applications have come under cyber attacks. Although cyber crimes and cyber threats have increased significantly in India yet cyber crimes prevention and network security in India are still far from perfect. India's preparedness to tackle growing cyber crimes and cyber attacks is not proper and we do not have any cyber law polity in India. In fact, cyber attacks and cyber terrorism preparedness of India is missing at all. Cyber terrorism is a concept that is closely related to national security and cyber security of any nation. While the definition and nature of cyber terrorism is still debatable yet none cant doubt about the use of information and communication technology (ICT) for attacking crucial computer systems of others, says Praveen Dalal, India's leading techno-legal expert. While both men and women are affected by cyber stalking, a survey of the characteristics of 'victims' finds that amongst users from the ages of 18-32, victims are predominantly females. Cases of cyber harassment continue to appear in the media, many go unresolved.

It is an example of social transformation that is changing social ideology, values and social relationship gradually not in our society/national but also globally. According to User Data of the huge multinational company Yahoo, (which were submitted to the China State Government under the discourse of "national security"), some kinds of cybercrimes are given more weight than others, and perhaps unsurprisingly, violence against women are more easily de-priotised in this matter.

Lack of cooperation from foreign-based websites in just one of many hindrances to the resolution of cybercrime cases. Other factors include understaffed cybercrime cells within police departments; lack of IT knowledge of police, judges and prosecutors who must then rely on private professionals for expert help; and legislation that does not provide existing cybercrime cells with enough authority to take cases to completion. Pavan Duggal, president of cyberlaws.net and a well- 
known Indian advocate against cybercrime, and other critics of India's IT Act find that existing legislation is insufficient (Pavan Duggal 5 July 2004. What's wrong with out cyber laws-Express Computer). To compound thest problems, many victims of cybercrime are unwilling to file their cases with the authorities. The true magnitudes of cybercrime, as well as demographic statistics on perpetrators and victims, are unknown because most incidents of cybercrime go unreported. Duggal has observed that "In 2006, I did a survey to find out how many cybercrime reports were filed and I was shocked to discover that only $10 \%$ of the cases were reported and that one percent got registered as FIRs. The reason behind this is that the victim is either scared of police harassment or wrong media publicity" (Vinita Gupta. 19 November 2007. No End to Cyber Crime Expres Computer).

\section{Part-IV}

\section{POLICY MEASURES AND SUGGESTIONS}

In order to highlight the growing threat to information security in India and focus related actions, Government had set $\mathrm{p}$ an Inter Departmental Information Security Task Force (ISTF) with National Security Council as the nodal agency. The Task Force studies and deliberated on the issues such as

- National Information Security Threat Perceptions

- Critical Minimum Infrastructure to be protected

- Ways and means of ensuring Information Security including identification of relevant technologies.

- Legal procedures required to ensure Information Security.

- Awareness, Training and Research in Information Security.

In line with the recommendations of the ISTF, the following initiatives have been taken by the Government-

- Indian Computer Emergency Response Team (CERT-In) has been established to respond to the cyber security incidents and take steps to prevent recurrence of the same.

- PKI infrastructure has been set up to support implementation of Information Technology Act and promote use of Digital Signatures.

- Government has been supporting R \& D activities through premier Academic and Public Sector Instructions in the country.

- Information Security Police Assurance Framework for the protection of Government cyberspace and critical infrastructure has been developed.

- The Government has mandated implementation of Security Policy in accordance with the Information Security Standard ISO 27001

- Currently in India 246 organization have obtained certification against the Information Security Standard ISO 27001 as against total number of 2814 ISMS certificates issued worldwide, Majority of ISMS certificates issued in India belong to IT/ITES/BPO sectors.

- Security Auditors have been empanelled for auditing, including vulnerability assessment \& penetration testing of computer systems \& networks of various organizations of the government, critical infrastructure organizations and those in other sectors of the India economy.

\section{SOME SUGGESTIONS ARE GIVEN TO REDUCE THIS PROBLEM-}

1. The IT infrastructures significances to the country has gained visibility in the recent years due to cyber attacks and rapid growth in identity theft and financial frauds. These events have made it increasingly clear that the security of the IT infrastructure has become a key strategic interest to the Government. 
2. The Government has a different but equally important role to play in cyber security assurance in the form of long-term strategies. In this direction, the deliberations of the National Information Board (NIB), National Security Council (NSC) have stressed the importance of a national strategy on cyber security, development of national capabilities for ensuring adequate protection of critical information infrastructures including rapid response and remediation to security incident, long terms investments in infrastructure facilities, capacity building and $\mathrm{R} \& \mathrm{P}$.

3. Public-private partnership is a key component of Cyber Security Strategy. These partnership can usefully confront coordination problems. They can significantly enhance information exchange and cooperation. Public-private engagement will take a variety of forms and will address awareness, training, technological improvements, vulnerability remediation, and recovery operations.

4. The Indian Minister of State in the communications and IT ministry has discussed amending the IT Act to tackle new forms of cybercrimes like phishing, identity theft, and cyber stalking by making internet usage more transparent.

5. Governments can facilitate this process by taking legislative measures that ensure human rights are protected online just as they are physical spaces.

\section{References}

1. Gupta, K.L. and Sharma D.D. (2000), "Sociology." published by Sahitya Bhawan Publication, Agra.

2. Henslin, J.M. (1995), "Sociology-A down to Earth Approach," published by Allyn and Bacon, Singapore.

3. http://en.wikipedia,org/wiki/Social_transformation

4. http://rajee.sulekha.com/blog/post/2007/06/ongoing-social-transformation -in-india html.

5. http://www.defence.pk/forums/india-defence/100765-india-facing-serious-cyber-threats,html

6. http://www.facebook.com/pages/Social-transformation/115980275079190

7. http://www.merinews.com/article/role-of-women-in-social-transformation/ 15751822.s html

8. Pavan Duggal, 5 July 2004. What's wrong with our cyber laws. Express Computer.

9. Sociology, From Wikipedia, the free encyclopedia.

10. Vinita Gupta. 19 November 2007. No End to Cyber Crime. Express Computer. 